\title{
ОЦЕНКА СЕЙСМОСТОЙКОСТИ ЗДАНИЙ И СООРУЖЕНИЙ НА ОСНОВЕ МЕТОДА СТОЯЧИХ ВОЛН
}

\author{
Хорошавин Е. А. канд. техн. наук, доцент каф. СК и УС \\ Сибирский федеральный университет
}

Метод стоячих волн, разработанный ГС СО РАН (А.Ф.Еманов) для детального исследования физического состояния зданий и сооружений на уровне элементов конструкций, использует собственные колебания множества частот, а не главной частоты как другие методы. Изучается поле стоячих волн с любой детальностью, что даёт возможность получать информацию о локальных скрытых дефектах сооружений. Количественная интерпретация стоячих волн позволяет получить объективные оценки сейсмостойкости.

Большим преимуществом данного метода является использование естественных микросейсмических шумов здания, а не искусственных источниковвибраторов, приводящих к частичным разрушениям несущих конструкций и отделочных элементов.

СУТЬ МЕТОДА

В основу метода положены следующие утверждения:

1. При воздействии микросейсмических колебаний на здание (инженерное сооружение) отличия формирующихся в нём стоячих волн, зарегистрированных в двух произвольных точках, описываются линейной системой, характеристика которой не зависит от времени.

2. При воздействии микросейсмических колебаний на здание отличия бегущих волн, зарегистрированных в двух произвольных точках, не могут быть описаны линейной системой, характеристика которой не зависит от времени.

3. Линейные связи в изменениях стоячих волн, регистрируемых в двух точках, существуют для каждой пары одноимённых компонент регистрируемых колебаний.

4. Нормированные на свой максимум колебания каждой из нормальных мод не зависят от положения источника и от спектра вошедшего в замкнутый объём колебания.

Здания является не сплошным телом, а представляет систему, состоящую из элементов (стены, колоны, перекрытия и др.). В сооружении происходят колебания двух порядков: 1-й порядок - колебание сооружения как общей системы, основанной на грунте; 2-й порядок - колебание элементов сооружения, входящих в общую систему, например поперечные колебания колонны в пределах этажа, панели стены и.т.п. При сейсмических воздействиях в сооружении возникают напряжения, превосходящие предел упругости, а в отдельных случаях предел прочности.

Учитывая, что стоячие волны являются резонансами здания, то их изучение позволяет сделать выводы об общих закономерностях колебаний при любых типах сейсмического воздействия на здания. Поскольку поле стоячих волн не зависит от источника колебаний, мы можем, исследуя стоячие волны, формирующиеся при воздействии на здание микросейсмических колебаний, получать информацию, по которой объективно рассчитываются резонансные колебания при крупных сейсмических воздействиях. 
По разработанному на стадии формирования программы испытаний графику, малоканальной аппаратурой выполняется последовательная регистрация сейсмических микрошумов. На каждом этаже регистрация выполняется на всех несущих элементах конструкции. При этом в непрерывном режиме ведется регистрация в нескольких опорных точках.

Обработка данных регистрации микросейсмических колебаний конструкций здания выполняется в программно-алгоритмическом комплексе разработанным на основе методологии пересчета стоячих волн (ГС СО РАН, А.Ф.Еманов).

В результате обработки записей микрошумов, для обследуемого здания получаем одновременные записи стоячих волн из разновремённых, последовательных наблюдений с опорными точками. Процедура обработки сводится к следующим операциям:

- $\quad$ Нахождение частотных характеристик линейных систем;

- Формирование независимой реализации процесса колебаний опорных точек при сейсмическом воздействии на исследуемый объект; объекта.

Пересчёт стоячих волн из опорной точки во все точки обследуемого

Для построения взаимосвязей между точками здания и построения модели распространения и передачи волновых эффектов рассчитываются спектры когерентности и спектры погрешностей. Спектр когерентности является мерой линейности связи колебаний между двумя точками инженерного сооружения.

Заданные временные серии ускорений (сценарные землетрясения), скоростей и смещений грунта пересчитываются на все точки здания на основе построенной модели волновых связей. Исходя из полученных расчетных пиковых и интервальных характеристик движения, оцениваются возникающие нагрузки во всех элементах конструкции.

При сопоставлении расчетных с максимально допустимыми нагрузками получаются оценки сейсмостойкости здания и выделяются проблемные элементы.

\section{КОМПЛЕКС РАБОТ ПО УСО И СМР}

Одним из важнейших условий при оценке сейсмостойкости здания, является использование не интегрального показателя - балльности, а параметров сейсмических воздействий характерных именно для данной площадки - пиковые ускорения, преобладающие периоды колебаний, длительность сотрясений и соответствующие этим параметрам модельные записи землетрясений.

Для получения модельных акселерограмм, а также временных серий скоростей и смещений грунта планируется выполнить комплекс работ по УСО и CMP.

\section{Уточнение сейсмической опасности (УСО):}

Адекватность набора модельных землетрясений обеспечивает точность оценок сейсмостойкости и определяется объективностью региональной модели сейсмичности - корректностью параметризации сейсмогенных структур (повторяемость сейсмических событий, точность картирования активных разломов, типы подвижек и т.д.). Основная задача на стадии УСО - детализация модели вероятных очагов землетрясений.

При формировании набора сценарных воздействий выполняется деагрегационный анализ модельной сейсмичности, и определяются параметры землетрясений с заданной вероятностью превышения на площадке строительства расчетной интенсивности за нормативный период времени (расстояние до гипоцентра, 
глубина гипоцентра, магнитуда, тип подвижки, взаимное положение плоскости подвижки и исследуемой площадки, и др.). На основе полученной информации моделируются временные серии укореняй, скоростей и смещений скального основания под площадкой.

\section{Сейсмическое микрорайонирование:}

Для оценки вклада в сотрясаемость сейсмореализующего слоя (рыхлых отложений между скальным основанием и фундаментом здания) выполняется комплекс инженерно-геофизических исследований. Строятся сейсмогеологические модели (СГМ) грунтового слоя площадки содержащие необходимые данные (геологический разрез, плотности слоев, скорости распространения сейсмических волн, уровень грунтовых вод и т.д.).

В результате пересчета подвижек скального основания через СГМ получаем записи временных серий ускорений, скоростей, движений в каждой точке грунтового комплекса под зданием непосредственно передающиеся на фундамент.

\section{Примеры использования описанной методики:}

1. Плотина Саяно-Шушенской ГЭС

2. Плотина Красноярской ГЭС

3. Главный корпус Национального банка Бурятии г. Улан-Удэ

4. Институт физики полупроводников СО РАН г. Новосибирск

5. Свято-ОдигитриевскИЙ собор в г. Улан-Удэ

6. Омский драматический театр

7. Промышленные объекты г. Кызыл, г. Сорск

8. Московский государственный строительный университет, г. Москва

9. Комплекс зданий "Северный парк", г. Москва

10. Объекты "Минатом". 